\title{
The role of proto-oncogene GLI1 in pituitary adenoma formation and cell survival regulation
}

\author{
Katharina Lampichler ${ }^{1}$, Patricio Ferrer ${ }^{1}$, Greisa Vila', Mirjam I Lutz ${ }^{2}$, Florian Wolf ${ }^{3}$, \\ Engelbert Knosp ${ }^{4}$, Ludwig Wagner ${ }^{5}$, Anton Luger ${ }^{1}$ and Sabina Baumgartner-Parzer ${ }^{1}$ \\ ${ }^{1}$ Division of Endocrinology and Metabolism, Department of Internal Medicine III, ${ }^{2}$ Clinical Institute of Neurology \\ ${ }^{3}$ Department of Biomedical Imaging and Image-Guided Therapy, ${ }^{4}$ Division of Neurosurgery, Department of Surgery, \\ and ${ }^{5}$ Division of Nephrology, Department of Internal Medicine III, Medical University of Vienna, \\ Waehringer Guertel 18-20, A-1090 Vienna, Austria
}

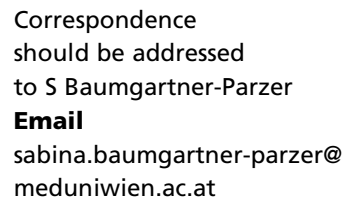

\begin{abstract}
The Hedgehog $(\mathrm{Hh})$ pathway is an important regulator of early tissue patterning and stem cell propagation. It was found to be aberrantly activated in numerous types of human cancer and might be relevant in cancer stem cells. The identification of adult stem cells in the pituitary raised the question if tumor-initiating cells and Hh signaling are involved in pituitary adenoma formation. The present study aimed at the evaluation of Hh signaling in relation to stem cell and cell cycle markers in 30 human pituitary adenomas and in cultured murine adenoma cells. Therefore, expression levels of components of the Hh pathway, stem cell marker SOX2, cell cycle regulator tumor-protein 53 (TP53), proliferation marker Ki67 (MKI67) and superoxide dismutase 1 (SOD1) were evaluated in 30 human pituitary adenomas in comparison to control tissue. Modulation of cell function and target gene expression by the inhibition and activation of the Hh pathway were studied in murine adenoma cells. We show that transcription factor glioma-associated oncogene 1 (GLI1) is overexpressed in $87 \%$ of all pituitary adenomas. The expression of GLI1 significantly correlated with that of SOX2, TP53, MKI67 and SOD1. Inhibition of GLI1 resulted in the downregulation of the above genes and severe cell death in mouse adenoma cells. On the other hand, activation of the $\mathrm{Hh}$ pathway increased cell viability and target gene expression. In conclusion, our findings point toward an alternative, ligand-independent Hh pathway activation with GLI1 playing a major role in the cell survival of pituitary adenoma cells.
\end{abstract}

\section{Key Words}

- Hedgehog

- GLI1

- pituitary adenoma

- stem cells

\section{Introduction}

The anterior pituitary gland is a key regulator of the endocrine system. During the life-span it undergoes extensive remodeling responding to metabolic changes and is therefore prone to tumor formation. Pituitary adenomas are the most common type of tumors arising in the sellar region, and although usually displaying benign growth behavior, they frequently cause severe morbidity in affected individuals. Functioning adenomas are associated with the uncontrolled secretion of pituitary hormones, whereas nonfunctioning adenomas can expand into functionally important adjacent structures (Ezzat et al. 2004, Melmed 2011).

High-throughput technologies made it apparent that tumors are highly heterogeneous resulting in the

Published by Bioscientifica Ltd.
Endocrine-Related Cancer (2015) 22, 793-803 
distinction of several clinical and molecular subtypes within one tumor entity (De Sousa et al. 2013). This heterogeneity is currently explained by two alternative but not necessarily mutually exclusive concepts of tumor formation. According to the clonal evolution model, adaptation to the tumor microenvironment as well as mutations and epigenetic modifications select for superior clones with similar proliferation and differentiation potential. In contrast, the cancer stem cell (CSC) model is based on the hypothesis that tumor initiation, maintenance and recurrence are driven by tumor-initiating CSCs. This rare population of tumor-initiating cells seems to share common pathways with embryonic and tissue stem/ progenitor cells and can therefore be identified through the expression of specific marker genes (Frank et al. 2010).

The recent characterization of stem cells in the adult pituitary gland raised the question if the CSC model could also be relevant in the pathogenesis of pituitary adenomas (Chen et al. 2005, Garcia-Lavandeira et al. 2009). Xu et al. (2009) reported the isolation of putative tumor-initiating cells from human pituitary adenomas. These clones were able to self-renew, had a differentiation potential for multiple pituitary cell lineages, expressed several stem/ progenitor-associated marker genes and initiated pituitary tumor formation after transplantation into immunodeficient mice. Further studies indicated that the stem cell regulator pathway Wnt/ $\beta$-catenin, stem/progenitor cell transcription factor Sox2, chemokine receptor CXCR4 and stem cell factor BMI1 as well as the progenitor cell marker Pax7 could play a potential role in human and mouse pituitary adenoma formation (Vankelecom \& Chen 2014). Such assumption is strengthened by the detection of a side population in human pituitary adenomas that could represent tumor-initiating cells due to the expression of multidrug transporters, oncogenes and components of several stem cell pathways (Vankelecom \& Gremeaux 2010). Moreover, craniopharyngiomas arising from embryonic pituitary tissue were found to express the stem cell markers SOX2, SOX9, OCT4, KLF4 and $\beta$-catenin (Gaston-Massuet et al. 2011, Andoniadou et al. 2012, Garcia-Lavandeira et al. 2012).

The Hedgehog (Hh) pathway is involved in embryogenesis and tissue repair as a regulator of developmental processes, stem cell maintenance and cell proliferation (Briscoe \& Therond 2013). The Hh ligand sonic Hh (SHH) was shown to be mandatory for normal pituitary development because downregulation of the Hh pathway in mice results in pituitary hypoplasia (Treier et al. 2001). Similar effects could be seen in zebrafish in which attenuation of the Hh signaling severely disrupts pituitary organogenesis (Herzog et al. 2003, Sbrogna et al. 2003). The Hh pathway is frequently activated in several human cancer types and assumed to contribute to tumor formation, progression, recurrence and therapy resistance by maintaining the CSC character (Xie et al. 2013). The downstream mediators of the Hh signaling are the GLI family of transcription factors that alter target gene expression. The main activator in tumor pathogenesis is thought to be glioma-associated oncogene 1 (GLI1).

Because there is only limited knowledge on a potential role of the Hh signaling in pituitary oncogenesis, the present study evaluated the expression of key players of the Hh pathway as well as other stem cell and proliferation markers in 30 human pituitary adenomas. Moreover, the Hh pathway was manipulated in the mouse pituitary adenoma cell line AtT-20 to study effects on target gene expression, cell proliferation and cell survival.

\section{Material and methods}

\section{Patient samples}

Thirty human pituitary adenomas were surgically removed at the Department of Neurosurgery, Medical University of Vienna, Austria, and immediately snap-frozen in liquid nitrogen. All patients gave written consent prior to the operation. Patient and tumor details are summarized in Table 1 . Three human postmortem pituitaries and healthy pituitary tissue obtained from three patients who underwent surgery due to a pituitary cyst were used as control tissue. The study was approved by the ethics committee of the Medical University of Vienna, Austria (EK No. 018/2004).

\section{Tumor volume determination}

Magnetic resonance imaging (MRI) and computed tomography (CT) scans obtained the day before surgery were available from 23 patients. CT scans were performed on two patients due to various contraindications for MRI. Seven patients had scans from outside institutions and were not available for volume determination. Tumor volume was calculated using OsiriX imaging processing software (Pixmeo, Geneva, Switzerland) at the Department of Radiology, Medical University of Vienna, Austria.

\section{Cell culture}

Mouse corticotropinoma cells from the cell line AtT-20 (American Type Culture Collection; passages 28-32) were maintained in $75 \mathrm{~cm}^{2}$ cell culture flasks in DMEM, $10 \%$ fetal bovine serum, $2 \mathrm{mM}$ glutamine and $10^{5} \mathrm{U} / 1$

Published by Bioscientifica Ltd 
Table 1 Patient and tumor details analyzed in the present study

\begin{tabular}{|c|c|c|c|}
\hline No. & Sex & $\begin{array}{c}\text { Age } \\
\text { (onset) }\end{array}$ & Symptoms \\
\hline 1 & $\mathrm{~F}$ & 73 & Aphasia, difficulty in concentration \\
\hline 2 & M & 41 & Acromegaly \\
\hline 3 & $\mathrm{~F}$ & 42 & Nausea \\
\hline 4 & $\mathrm{~F}$ & 63 & Vertigo, bitemporal hemianopsia \\
\hline 5 & $\mathrm{M}$ & 68 & Progressive vision impairment \\
\hline 6 & $\mathrm{~F}$ & 32 & None \\
\hline 7 & M & 66 & Acromegaly \\
\hline 8 & $\mathrm{M}$ & 48 & Vision impairment \\
\hline 9 & $\mathrm{~F}$ & 42 & Cushing's disease \\
\hline 10 & $\mathrm{~F}$ & 16 & Amenorrhea, galactorrhea \\
\hline 11 & $\mathrm{~F}$ & 30 & $\begin{array}{l}\text { Vertigo, hazy vision, amenorrhea, } \\
\text { galactorrhea }\end{array}$ \\
\hline 12 & M & 52 & $\begin{array}{l}\text { Vision impairment, bitemporal } \\
\text { hemianopsia }\end{array}$ \\
\hline 13 & $\mathrm{M}$ & 68 & Bitemporal hemianopsia \\
\hline 14 & $\mathrm{M}$ & 49 & Vertigo, double vision, constant headache \\
\hline 15 & $\mathrm{~F}$ & 29 & Amenorrhea, galactorrhea, weight gain \\
\hline 16 & M & 51 & $\begin{array}{l}\text { Vision impairment, bitemporal } \\
\text { hemianopsia }\end{array}$ \\
\hline 17 & $\mathrm{~F}$ & 62 & Hazy vision \\
\hline 18 & $\mathrm{M}$ & 33 & Acromegaly \\
\hline 19 & $\mathrm{M}$ & 51 & Vision impairment \\
\hline 20 & $\mathrm{M}$ & 69 & Vision impairment \\
\hline 21 & $\mathrm{M}$ & 56 & Emesis, damaged vestibular nerve \\
\hline 22 & $\mathrm{M}$ & 42 & Acromegaly \\
\hline 23 & $\mathrm{~F}$ & 37 & Acromegaly \\
\hline 24 & $\mathrm{M}$ & 50 & Oculomotor nerve palsy \\
\hline 25 & $\mathrm{~F}$ & 45 & NA \\
\hline 26 & $\mathrm{M}$ & 44 & Acromegaly, hypertension \\
\hline 27 & $\mathrm{~F}$ & NA & NA \\
\hline 28 & $\mathrm{~F}$ & 25 & Cushing's disease \\
\hline 29 & $\mathrm{M}$ & 47 & Fatigue, weakness, headaches \\
\hline 30 & $\mathrm{~F}$ & 52 & Acromegaly \\
\hline
\end{tabular}

\begin{tabular}{|c|c|}
\hline $\begin{array}{l}\text { TU volume } \\
\qquad\left(\mathrm{cm}^{3}\right)\end{array}$ & Expression \\
\hline 7.07 & FSH \\
\hline 2.28 & $\mathrm{GH}, \mathrm{PRL}$ \\
\hline 7.74 & None \\
\hline 20.4 & $\mathrm{LH}$ \\
\hline 16.39 & None \\
\hline 3.99 & FSH, TSH, PRL \\
\hline 1.06 & $\mathrm{GH}, \mathrm{FSH}, \alpha$-chains \\
\hline 4.29 & FSH, $\alpha$-chains \\
\hline 50 & ACTH, FSH, $\alpha$-chains \\
\hline 0.61 & PRL \\
\hline 15.57 & None \\
\hline 27.74 & None \\
\hline 20.71 & None \\
\hline 9.32 & None \\
\hline NA & PRL \\
\hline 3.26 & None \\
\hline 3.36 & None \\
\hline 3.06 & $\mathrm{GH}$ \\
\hline 9.63 & АCTH \\
\hline NA & None \\
\hline 7.65 & None \\
\hline NA & $\mathrm{GH}$ \\
\hline 0.78 & $\mathrm{GH}, \alpha$-chains \\
\hline 50.08 & ACTH \\
\hline NA & None \\
\hline NA & $\mathrm{GH}, \mathrm{ACTH}$ \\
\hline NA & None \\
\hline 0.99 & ACTH \\
\hline 15.63 & None \\
\hline NA & $\mathrm{GH}, \alpha$-chains \\
\hline
\end{tabular}

\begin{tabular}{|c|c|}
\hline Relapse & $\begin{array}{c}\text { GLI1 } \\
\text { expression }\end{array}$ \\
\hline $\mathrm{N}$ & 4 \\
\hline $\mathrm{N}$ & 4 \\
\hline $\mathrm{N}$ & 3 \\
\hline $\mathrm{N}$ & 3 \\
\hline $\mathrm{N}$ & 3 \\
\hline $\mathrm{N}$ & 3 \\
\hline $\mathrm{N}$ & 4 \\
\hline $\mathrm{N}$ & 3 \\
\hline Y & 4 \\
\hline $\mathrm{N}$ & 3 \\
\hline $\mathrm{N}$ & 4 \\
\hline $\mathrm{N}$ & 4 \\
\hline $\mathrm{N}$ & 4 \\
\hline $\mathrm{N}$ & 3 \\
\hline $\mathrm{N}$ & 2 \\
\hline Y & 3 \\
\hline $\mathrm{N}$ & 4 \\
\hline $\mathrm{N}$ & 1 \\
\hline $\mathrm{N}$ & 3 \\
\hline $\mathrm{N}$ & 3 \\
\hline $\mathrm{N}$ & 3 \\
\hline $\mathrm{N}$ & 3 \\
\hline $\mathrm{N}$ & 2 \\
\hline Y & 1 \\
\hline NA & 4 \\
\hline $\mathrm{N}$ & 3 \\
\hline NA & 4 \\
\hline Y & 1 \\
\hline Y & 3 \\
\hline $\mathrm{N}$ & 1 \\
\hline
\end{tabular}

F, female; M, male; Age, the age of symptom onset; TU, tumor; NA, scans from outside institutions were not available, patients lost during follow-up; ACTH adrenocorticotropin; GH, growth hormone; PRL, prolactin; TSH, thyroid stimulating hormone; $F S H$, follicle-stimulating hormone; $\mathrm{LH}$, luteinizing hormone Hormone expression was routinely analyzed and stated in the patient's medical records. GLI1 expression extent was compared to healthy pituitaries and is listed in groups: 1 , expression $\leq$ control; 2 , one- to tenfold increase; 3 , ten- to 100 -fold increase; $4,>100$-fold increase.

penicillin-streptomycin (Invitrogen) at $37^{\circ} \mathrm{C}$ and $5 \% \mathrm{CO}_{2}$. Cells were passaged at $80 \%$ confluency and seeded into 12-well plates at 150000 cells/well as previously described (Reiter et al. 2011). Cells were treated with Hh agonist purmorphamine (Cayman Chemical, Ann Arbor, MI, USA, Cat. No. 10009634), Smoothened antagonist GDC-0449 (Vismodegib; Selleckchem, Houston, TX, USA, Cat. No. S1082), GLI antagonist GANT61 (Sigma-Aldrich, Cat. No. G9048) or an equivalent amount of DMSO as solvent control.

\section{RNA isolation}

For total RNA isolation from pituitary adenomas, $100-200 \mathrm{mg}$ frozen tissue were homogenized in $1 \mathrm{ml}$ QIAzol Lysis Reagent (Qiagen, Cat. No. 79306) using the Precellys 24 homogenizer (Peqlab, Erlangen, Germany,
Cat. No. 91-PCS24). For cell culture, $0.5 \mathrm{ml}$ of QIAzol Lysis Reagent was added to each well (12-well plate) and cells were scraped off manually. RNA isolation was then continued according to the manufacture's protocol, and 100 ng of RNA were reverse transcribed using Superscript II (Invitrogen, Cat. No. 18064) and random primers.

\section{Quantitative real-time PCR}

RT-qPCR was performed using commercially available TaqMan Gene Expression Assays (Applied Biosystems, Cat. No. 4331182; Assay IDs: Hs02758991_g1, Hs01034249_m1, Hs01032443_m1, Hs00533490_m1, Hs01053049_s1, Hs00179843_m1, Hs01110766_m1). The relative standard curve method was used to determine the gene expression extent of the following genes:

Published by Bioscientifica Ltd. 
GLI1, sex-determining region Y-box 2 (SOX2), superoxide dismutase 1 (SOD1), SHH, tumor-protein 53 (TP53), marker of proliferation Ki67 (MKI67) and glyceraldehyde-3phosphate dehydrogenase (GAPDH) for human samples. The qPCR gene product was ligated into a pGEM-T Easy Vector (Promega, Cat. No. A1360), transformed into $50 \mu \mathrm{l}$ One Shot Top 10 Chemical Competent cells (Invitrogen, Cat. No. C4040-03) and grown over night at $37^{\circ} \mathrm{C}$ on Lysogeny Broth (LB) agar plates supplemented with $100 \mu \mathrm{g} / \mathrm{ml}$ of ampicillin. On the next day, single cultures were inoculated in LB medium containing $50 \mu \mathrm{g} / \mathrm{ml}$ ampicillin over night at $37^{\circ} \mathrm{C}$. Plasmid DNA was purified (Pure Link Quick Plasmid Miniprep Kit, Invitrogen, Cat. No. K210011) and successful integration of the target gene was determined with RT qPCR. Plasmid DNA was also run on a $1 \%$ agarose gel to check for RNA contamination. Standard curves for target genes and endogenous control in a 1-log dilution range were included on every RT-qPCR plate. Relative gene expression was normalized to the endogenous control GAPDH and analyzed in duplicates.

For cell culture experiments, cells were maintained for $24 \mathrm{~h}$ and treated with GANT61 $(5,10,15$ and $20 \mu \mathrm{M})$ and Purmorphamine $(0.5,1,2$ and $4 \mu \mathrm{M})$. Gene expression was measured using the $2^{-\Delta \Delta C t}$ method and the DMSOtreated samples as reference with Ubiquitin $C$ as endogenous control. TaqMan Assay IDs for the target genes are as follows: Mm99999915_g1, Mm01731290_g1, Mm01278617_m1, Mm01344233_g1, Mm03053810_s1, Mm00494654_m1 and Mm02525934_g1. RT-qPCR was performed in quadruplets.

\section{Immunofluorescence stainings}

Cryosections $(6-8 \mu \mathrm{m})$ of the pituitary adenomas were brought to room temperature and fixed in acetone for $10 \mathrm{~min}$. Sections were stained with primary antibodies for GLI1 (Abcam, Cambridge, GB, Cat. No. ab49314; 1:100), SOX2 (Abcam, Cat. No. ab75485; 1:100) and SOD1 (Abcam, Cat. No. ab20926; 1:100) and incubated at $4{ }^{\circ} \mathrm{C}$ in a wet chamber overnight. After PBS washes, sections were incubated with secondary antibodies (Alexa Fluor 488 goat anti-rabbit, Invitrogen, Cat. No. A11070; 1:200) and TRITC goat anti-mouse (Sigma, Cat. No. T5393; 1:200) at room temperature for $1 \mathrm{~h}$ and washed in PBS. Cell nuclei were stained using 4',6-diamidino-2phenylindole, dihydrochloride (DAPI) and slides were mounted with Vectashield (Vector Laboratories, Servion, Switzerland, Cat. No. H-1000). Matched isotype antisera were used instead of primary antibodies as control. Images were acquired using the LSM 700 laser scanning microscope and ZEN 2012 imaging software (both from Zeiss, Oberkochen, Germany).

\section{Immunohistochemistry stainings}

Formalin-fixed, paraffin-embedded postmortem pituitary and tumor tissue were cut into $5 \mu \mathrm{m}$ thick sections and pretreated with citrate buffer $(\mathrm{pH} 6)$ for $1 \mathrm{~h}$ in a steamer and then stained with anti-GLI1 antibody (rabbit polyclonal, Abcam, Cat. No. ab151796; 1:750) followed by the appropriate secondary system (Envision Dako cytomation) and DAB. For nuclear staining, Mayer's hemalum solution (Merck, Cat. No. 109249) was used. Pictures were taken with a Nikon Eclipse E600 microscope using ProgRes C5 (Jenoptik L.O.S) software.

\section{Cell viability analysis}

AtT-20 cells were maintained as described above and treated with Purmorphamine $(0.5,1,2$ and $4 \mu \mathrm{M})$, GANT61 $(5,10,15$ and $20 \mu \mathrm{M})$, GDC-0449 $(5,10,20$ and $25 \mu \mathrm{M})$, caspase-8 inhibitor $(70 \mu \mathrm{M}$; BD Biosciences, San Jose, CA, USA, Cat. No. 550380) or DMSO for $24 \mathrm{~h}$. Cells were stained with trypan blue (Invitrogen, Cat. No. 15250-061) and counted using Nikon's Eclipse Ti inverted microscope.

\section{Western blotting}

AtT-20 cells were harvested after $48 \mathrm{~h}$ and proteins were isolated using radioimmunoprecipitation assay (RIPA) lysis buffer containing protease and phosphatase inhibitors (cOmplete, Cat. No. 04693124001 and PhosSTOP, Cat. No. 04906845001, both from Roche). Precast tris glycine gels were loaded with $20 \mu \mathrm{g}$ of proteins and transferred to a PVDF membrane. The membrane was blocked with $1 \%$ BSA, and anti-GLI1 antibody (rabbit polyclonal, Abcam, Cat. No. ab151796; 1:700) was incubated over night at $4{ }^{\circ} \mathrm{C}$. Secondary antibody (rabbit polyclonal, Dako, Glostrup, Denmark, Cat. No. P0448; 1:4000) was incubated for $1 \mathrm{~h}$ at RT. For GAPDH, anti-GAPDH primary antibody (rabbit polyclonal, Santa Cruz; Cat. No. sc-25778; 1:3000) and the above secondary antibody were used.

\section{Statistical analysis}

For tumor gene expression, correlation analyses were performed using Spearman's rank correlation coefficient. For cell culture analyses, matched one-way ANOVA with a subsequent Dunnett's multiple comparisons test was

Published by Bioscientifica Ltd. 
performed. Results are expressed as mean \pm s.E.M. and considered statistically significant at a $P$ value $\leq 0.05$. Statistical significance is reported as following: not significant (NS) $P>0.05 ; \quad{ }^{*} P \leq 0.05 ; \quad{ }^{*} P \leq 0.01$; ${ }^{* *} P \leq 0.001 ;{ }^{* * *} P \leq 0.0001$. GraphPad Prism 6 software was used for data analyses.

\section{Results}

\section{GLI1 is expressed in human pituitary adenomas}

The expression of GLI1 was analyzed in 30 human pituitary adenomas by RT-qPCR. Detailed histological reports were available from all tumors, dividing them into 57\% hormone-positive and 43\% nonfunctioning pituitary adenomas. Patient and tumor details are summarized in Table 1. As indicated, all tested adenomas were found to express GLI1 although to various extents. Compared to normal pituitary tissue, 26 out of the 30 adenomas (87\%) showed overexpression of GLI1, whereas GLI1 expression was only detectable in three out of six pituitaries of healthy subjects. GLI1 expression was also confirmed on the protein level. The localization of GLI1 in healthy postmortem pituitary tissue is depicted in Fig. 1. In comparison, Fig. 2 shows an adenoma with only little GLI1 expression on the RNA level and another adenoma highly expressing GLI1. Immunohistochemistry (IHC) stainings confirmed our previous RT-qPCR results regarding GLI1 expression extent. GLI1 expression did not correlate with tumor volume, relapse rate or hormonal status.

\section{GLI1 expression correlates with stem cell and cell cycle markers}

To further evaluate the role of GLI1 expression in pituitary adenoma pathogenesis, the expression status of stem cell

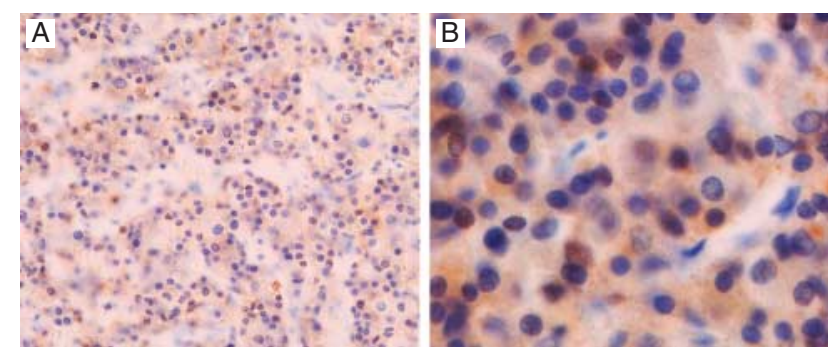

\section{Figure 1}

Localization of GLI1 in a postmortem healthy pituitary. GLI1 can be seen throughout the cytoplasm and in some nuclei. (A) $200 \times$ magnification; (B) $400 \times$ magnification. A full colour version of this figure is available at http://dx.doi.org/10.1530/ERC-15-0109.

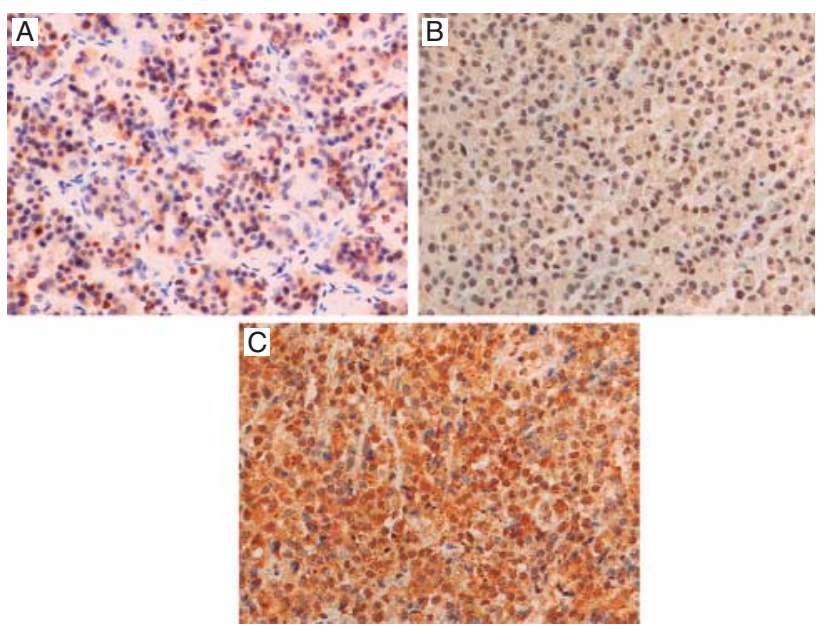

\section{Figure 2}

GLI1 expression in (A) normal pituitary, (B) pituitary adenoma not expressing GLI1 and (C) pituitary adenoma overexpressing GLI1. All magnifications are $100 \times$. A full colour version of this figure is available at http://dx.doi.org/10.1530/ERC-15-0109.

marker SOX2, tumor suppressor TP53, proliferation marker MKI67 and scavenger enzyme SOD1 was analyzed. We found that GLI1 expression correlates with SOX2 $(P \leq 0.001, r=0.581)$, TP53 $(P \leq 0.001, r=0.611)$, MKI67 $(P \leq 0.05, r=0.380)$ and SOD1 $(P \leq 0.001, r=0.589)$ expression. Out of the 30 adenomas tested, eight overexpressed SOX2 (27\%), 25 (83\%) TP53, 4 (13\%) MKI67 and 13 (43\%) SOD1. Furthermore, SOX2, TP53, MKI67 and SOD1 also exhibit significant correlations among each other. SOX2 correlated with TP53 $(P \leq 0.001, r=0.556)$, SOD1 $(P \leq 0.001, r=0.627)$ and MKI67 $(P \leq 0.05, r=0.402)$. TP53 and SOD1 expressions also correlated significantly $(P \leq 0.0001, r=0.833)$. MKI67 expression did not correlate with TP53 and SOD1 respectively. The Hh ligand $S H H$ was found to be overexpressed in 18 (60\%) of the tumors but did not correlate with any other analyzed genes including GLI1. Only 50\% of the control pituitaries expressed $S H H$. Expression of $\mathrm{Hh}$ receptors PTCH1/2 and SHH was described previously (Vila et al. 2005a).

Because we were particularly interested in the coexpression of GLI1, SOX2 and SOD1, further analyses of their interactions were performed using immunofluorescence stainings. On activation, GLI1 translocates into the cell nucleus where it induces the expression of its target genes. Immunofluorescence staining of cryosections of human pituitary adenomas confirmed the expression of GLI1 in these tumors. We found that GLI1 was mainly located in the cell nucleus rather than in the cytoplasm, representing its active state. The expression of GLI1 was not restricted to

Published by Bioscientifica Ltd 
A

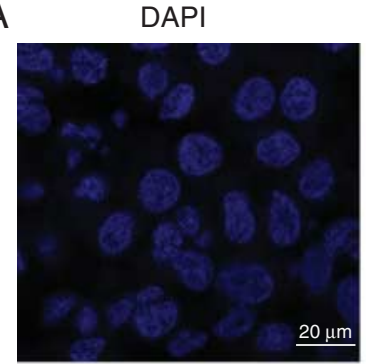

B

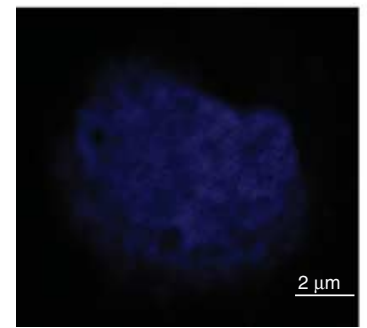

GLI1

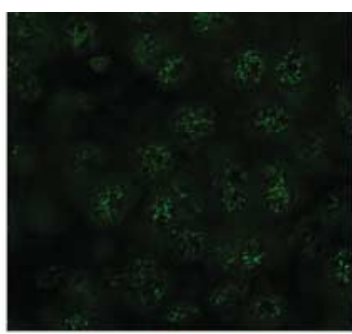

GLI1

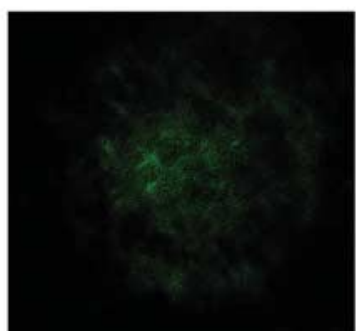

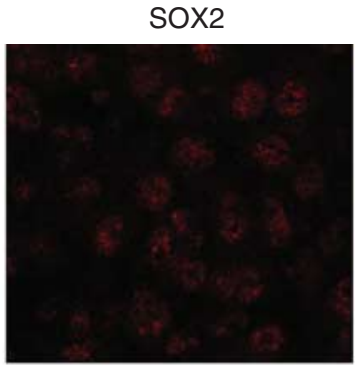

SOD1

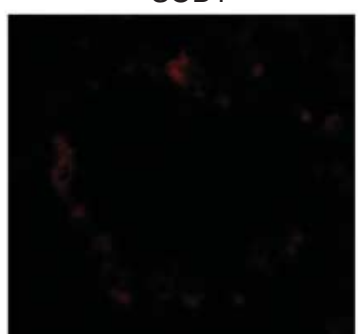

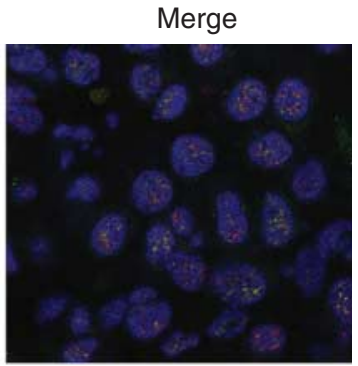

Merge

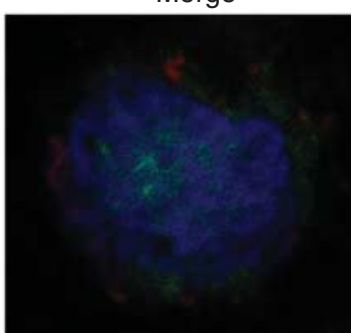

\section{Figure 3}

Immunofluorescence stainings of two nonfunctioning human pituitary adenomas. GLI1 is mainly located in the cell nucleus. (A) Co-localization of GLI1 and SOX2 in the cell nucleus spread across the tumor.

specific zones within the adenoma but seemed to follow a diffuse, homogenous expression pattern across the tumor (Fig. 3). By double staining SOX2 and GLI1, we could see that the SOX2 pattern closely resembled that of GLI1. SOD1, however, was expressed in the cytoplasm and co-localized with GLI1 in close proximity to the nucleus.

\section{Inhibition of GLI reduces cell viability in vitro}

Due to the overexpression of GLI1 seen in this study, we further evaluated the role of the Hh pathway in the mouse pituitary adenoma cell line AtT-20. GLI1 expression in AtT-20 cells was confirmed on the RNA and protein level (Fig. 4). We decided to downregulate Hh signaling at two different levels. Smoothened inhibitor GDC-0449 acts at the beginning of the cascade, while GANT61 inhibits activation of the transcription factors GLI1/2. A significant reduction in cell viability was already apparent after $24 \mathrm{~h}$ of treatment with GANT61 and GDC-0449 respectively (Fig. 5). Inhibiting the Gli proteins seemed to have a much stronger effect on cell viability than inhibiting the smoothened. That effect was clearly dose dependent for GANT61, as $5 \mu \mathrm{M}$ GANT61 reduced cell viability to about $30 \%$, whereas not a single viable cell was found at a dose of $20 \mu \mathrm{M}$ (Fig. 5A). GDC-0449 gradually led to decreased cell viability but with significant effects only seen at a dose of $25 \mu \mathrm{M}$ (Fig. 5B).
(B) Co-localization of GLI1 and SOD1; cropped image, images are shown in $400 \times$ magnification. A full colour version of this figure is available at http://dx.doi.org/10.1530/ERC-15-0109.

\section{Expression of Gli1, Mki67, Sox2, Trp53 and Sod1 is downregulated by GANT61}

Correlation analyses in human pituitary adenomas revealed a possible coexpression of GLI1 with SOX2, MKI67, SOD1 and TP53. Therefore, we treated AtT-20 cells with GANT61 for $24 \mathrm{~h}$ to test whether the inhibition of Gli actually affects expression of the above-mentioned genes. In line with our hypothesis, GANT61 dosedependently reduced gene expression of Gli1, Mki67, Sox2, Sod1 and Trp53 as summarized in Fig. 6. Gli1 expression was reduced by $50 \%$ at a dose of 5 and $10 \mu \mathrm{M}$ respectively (Fig. 6A). Expression of the proliferation marker Mki67 was reduced to $60 \%$ at $5 \mu \mathrm{M}$ GANT61 and $<10 \%$ at a dose of $20 \mu \mathrm{M}$ (Fig. 6B), and Sox 2 expression

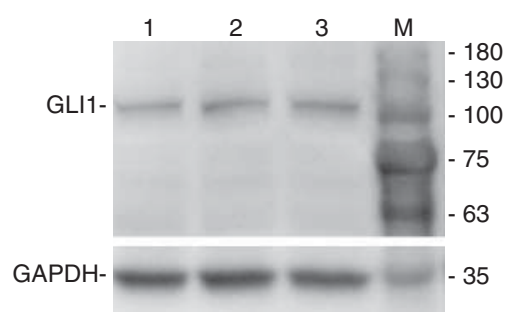

\section{Figure 4}

To confirm GLI1 expression in AtT20 cells, western blot analysis of untreated samples was performed (lanes 1-3). The predicted molecular weight of GLI1 is $118 \mathrm{kD}$. GAPDH was used as housekeeping control (37 kD).

Published by Bioscientifica Ltd 

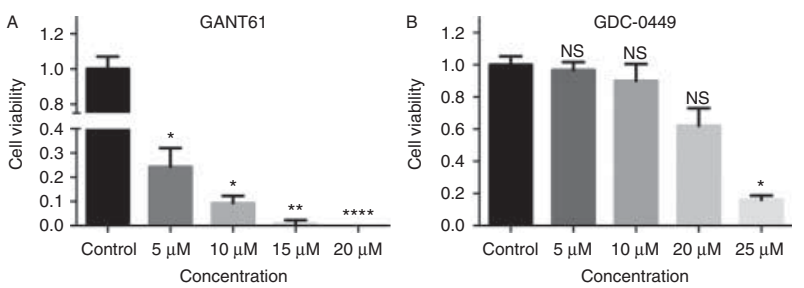

Figure 5

Cell viability analysis of AtT-20 mouse pituitary adenoma cells. Cells were treated with Gli antagonist GANT61 and smoothened antagonist GDC-0449 for $24 \mathrm{~h}$. Cell viability was determined with trypan blue. (A) Dosedependent reduction of cell viability using GANT61. (B) GDC-0449 significantly reduced cell viability at a dose of $25 \mu \mathrm{M}$. Calculations are based on the results of two separate experiments $(n=2)$. Each experiment was performed in quadruplets. Results are presented as mean \pm s.E.M. NS $=P>0.05 ; * P \leq 0.05 ; * * P \leq 0.01 ; * * * * P \leq 0.0001$.

was downregulated to $35 \%(5 \mu \mathrm{M})$ and $<10 \%(20 \mu \mathrm{M})$ (Fig. 6C). Sod1 expression was reduced to 60 and 30\% by 5 and $20 \mu \mathrm{M}$ GANT61 respectively (Fig. 6D), whereas Trp53 was diminished by $50 \%$ at $5 \mu \mathrm{M}$ and by $75 \%$ at $20 \mu \mathrm{M}$ GANT61 (Fig. 6E). These data indicate that inhibition of Gli is responsible for reduced cell viability of pituitary adenoma cells and that targeting of Gli also regulates Sox2, Mki67, Sod1 and Trp53 gene expression.

\section{Enhancing Hh signaling results in increased cell viability}

To further confirm the involvement of GLI1 signaling in the pathogenesis of pituitary adenomas, we activated the Hh pathway in AtT-20 cells with smoothened-agonist purmorphamine. Consistent with our previous data, purmorphamine increased cell viability in mouse adenoma cells. This effect seemed to be dose independent and already apparent at the low dose of $0.5 \mu \mathrm{M}$. Cell viability could be increased to 1.75- to 1.9-fold compared to DMSOtreated control samples (Fig. 7A). We further wanted to test if the GANT61-induced cell death could be partly reversed by purmorphamine; $10 \mu \mathrm{M}$ GANT61 induced cell death in $80 \%$ of the cells. Interestingly, $1 \mu \mathrm{M}$ purmorphamine combined with $10 \mu \mathrm{M}$ GANT61 increased cell viability by only $10 \%$, but $2 \mu \mathrm{M}$ purmorphamine given together with $10 \mu \mathrm{M}$ GANT61 enhanced cell viability by $30 \%$. Whereas purmorphamine alone could not dosedependently increase cell viability, antagonizing GANT61 is more effective at higher doses of purmorphamine. The effect of GANT61 could also be partly reversed by caspase- 8 inhibitor suggesting a caspase-dependent induction of apoptosis through GANT61 (Fig. 7B).

\section{Purmorphamine induces expression of Gli1, Mki67, Sox2, Trp53 and Sod1}

Gene expression analyses of purmorphamine-treated mouse adenoma cells confirmed our results. Purmorphamine dose-dependently activated the gene expression of Gli1, Mki67, Sox2, Trp53 and Sod1 (Fig. 8). Minor induction of gene expression was already seen at a dose of $0.5 \mu \mathrm{M}$ purmorphamine. At $1 \mu \mathrm{M}$, Gli1, Mki67 and Sod1 expression were significantly enhanced by 1.5 -fold. All genes except Sox 2 were highly induced at $2 \mu \mathrm{M}$ purmorphamine. At a concentration of $4 \mu \mathrm{M}$ purmorphamine, Gli1, Mki67 and Sod1 expression increased by more than 100\% and Trp53 expression was even three times higher than in DMSO-treated control samples (Fig. 8A, B, $\mathrm{D}$ and $\mathrm{E}$ ). Sox 2 expression was stimulated to a lesser extent because an increase of expression was only significant at a concentration of $4 \mu \mathrm{M}$ purmorphamine (Fig. 8C). Taken together, activation of Gli1 resulted in an increased gene expression of Mki67, Sox2, Trp53 and Sod1 in mouse adenoma cells.

\section{Discussion}

The Hh pathway is a crucial regulator of fetal development but is also found to be reactivated in several types of human cancer. Hh signaling seems to contribute to
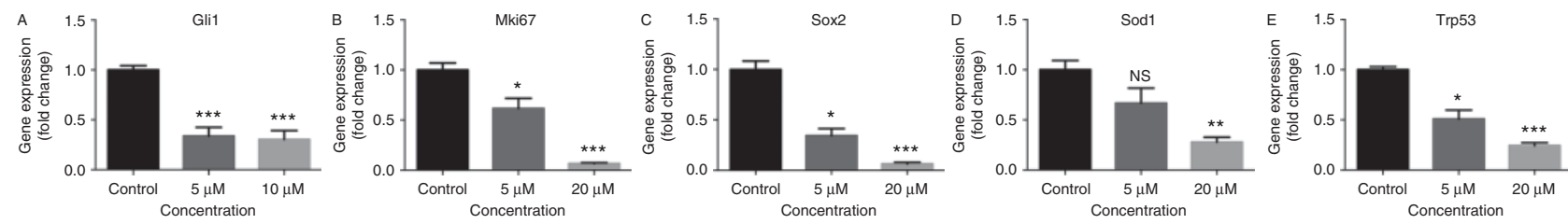

\section{Figure 6}

Gene expression levels after 24-h treatment with GANT61. (A) Gli1 expression could only be determined at 5 and $10 \mu \mathrm{M}$ GANT61 concentration. ( $B, C, D$ and $E$ ) The downregulation of the genes Mki67, Sox2, Sod1 and Trp53 at doses of 5 and $20 \mu \mathrm{M}$ GANT61. Calculations are based on the
(C) 2015 Society for Endocrinology Printed in Great Britain results of two separate experiments $(n=2)$. Each experiment was performed in quadruplet. Results are presented as mean \pm S.E.M. NS $=P>0.05 ; * P \leq 0.05 ;{ }^{*} P \leq 0.01 ; * * * P \leq 0.001$.

Published by Bioscientifica Ltd. 

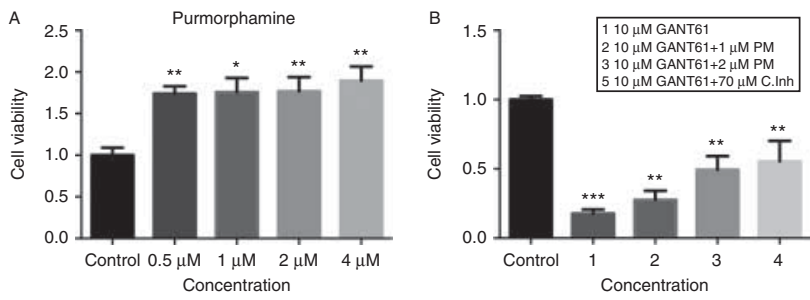

Figure 7

(A) AtT-20 cells were treated for $24 \mathrm{~h}$ with smoothened agonist purmorphamine, which resulted in a dose-independent increase in cell viability. (B) GANT61-induced reduction of cell viability could be partly reversed by purmorphamine (PM) and caspase-8 inhibitor (C.Inh). Calculations are based on the results of two separate experiments $(n=2)$. Each experiment was performed in quadruplets. Results are presented as mean \pm s.E.M. ${ }^{*} P \leq 0.05 ; * * P \leq 0.01 ; * * P \leq 0.001$.

oncogenesis through maintaining the stem cell character of stem cell-like cancer cells, which is in line with the CSC paradigm. The discovery of adult stem cells in the pituitary gland raised the question if tumor-initiating cells are also involved in the pathogenesis of pituitary adenomas. To provide another piece of evidence, we evaluated the expression of Hh pathway members, stem cell markers and cell cycle regulators in 30 human pituitary adenomas.

In the present paper we show that GLI1, the terminal transcription factor of the Hh pathway, is expressed in normal human pituitary tissue and pituitary adenomas. Only $50 \%$ of the pituitaries of healthy subjects express GLI1, whereas GLI1 expression is clearly upregulated in adenomas. This is in line with the aberrant activation of the Hh pathway found in several cancer types (Brechbiel et al. 2014). The expression of GLI1 shows great variability not just between healthy and tumor tissue but also within both groups. However, there was no tumor not expressing GLI1. We could confirm actual activation of GLI1 in pituitary adenomas due to its almost exclusive location in the cell nucleus.

In mammals, the main activator of the canonical $\mathrm{Hh}$ cascade is SHH, but several alternative, ligand-independent activating mechanisms have been identified in human cancers (Scales \& de Sauvage 2009). We hypothesize that this might also be the case in pituitary adenomas, as GLI1 expression is found in almost all tumors studied, whereas SHH expression is present in only $60 \%$ of the adenomas in our study, and even to a lesser extent in other studies (Vila et al. 2005a). GLI1 but not SHH expression also significantly correlated with stem cell marker SOX2, cell cycle regulator TP53, proliferation marker MKI67 and SOD1. Furthermore, inhibition of the Hh pathway in mouse adenoma cells was more effective on the level of Gli rather than upstream of the cascade. These findings could be explained by $\mathrm{SHH}$ signaling from adjacent structures (Treier et al. 2001) as well as SHH-independent activation of Gli1. As GLI1 signaling increases pituitary hormone secretion (Vila et al. 2005a), hypophysiotrophic hormones and cytokines might be possible GLI1 activators. Indeed, corticotropin-releasing hormone (CRH) upregulates Gli1 transcription in AtT-20 cells (Vila et al. 2005b). The SHH-independent GLI1 expression in pituitary tumors supports the hypothesis that GLI1 activation plays an important role in tumorigenesis, while the reduction in SHH expression is highly likely a compensatory mechanism.

This hypothesis was also confirmed by our functional experiments, as inhibition of endogenous GLI1 signaling in mouse pituitary adenoma cells resulted in a dosedependent reduction of cell viability and $\operatorname{Sox} 2, \operatorname{Tr} 553$, Mki67 and Sod1 gene expression. On the other hand, inhibition of smoothened, which indirectly activates Gli1 signaling, increased cell viability and target gene expression. These results confirm that increased endogenous Gli1 activity in pituitary adenoma cells is linked to increased cell viability.

SOX2 was found to be a key marker of adult stem cells in various tissues including the pituitary. Sox $2+$ cells in the mouse pituitary can self-renew and are multipotent, giving rise to any of the endocrine cell types of the gland (Gleiberman et al. 2008). Only recently, Sox $2+$ cells were

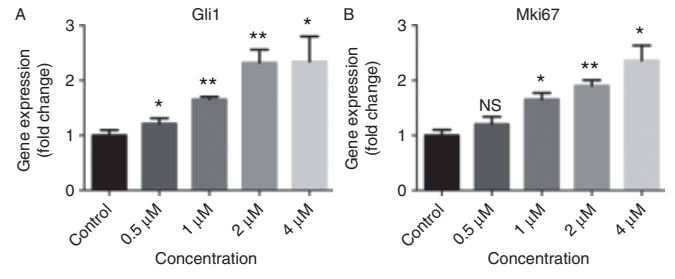

Figure 8

(A, B, C, D and E) Gene expression levels after $24 \mathrm{~h}$ purmorphamine treatment. Gene expression of Gli1, Mki67, Sox2, Sod1 and Trp53 could be dose-dependently stimulated by purmorphamine. Calculations are based on the results of three separate experiments $(n=3)$. Each experiment was performed in quadruplets. Results are presented as mean \pm S.E.M. NS $=P>0.05 ; * P \leq 0.05 ; * * P \leq 0.01 ; * \star * P \leq 0.001$.

Published by Bioscientifica Ltd. 
shown to contribute to pituitary tumor formation through paracrine signaling (Andoniadou et al. 2013). Similarly, Hh signaling was also found to be activated through paracrine mechanisms due to tight interactions of tumor cells with their microenvironment (Yauch et al. 2008). In line with this, synergy of SOX $2+$ cells and Hh signaling could be an important mechanism in the development of pituitary adenomas, possibly involving stem cell-like tumor cells.

Our data is also in line with previous findings that overexpression of p53 is commonly seen in pituitary adenomas. Whereas p53 is usually undetectable in healthy cells due to rapid degradation, mutations in the TP53 gene can lead to overexpression of oncogenic p53 in cancer cells (Janicke et al. 2008). Because TP53 mutations have only rarely been detected in pituitary adenomas, mutationrelated p53 upregulation seems not very feasible (Suliman et al. 2001, Tanizaki et al. 2007). However, oxidative stress is a general feature of cancer cells, going along with DNA damages and apoptosis. Cellular response to oxidative stress can activate antioxidant mechanisms including the expression of p53 and scavenger enzymes like the SOD family. In return, p53 can detect reactive oxygen species (ROS)-induced DNA damage and subsequently activates the expression of further antioxidant regulators (Trachootham et al. 2009).

Although our findings of an increased TP53 and SOD1 expression fit well into the mentioned scenario, they do not allow any conclusions whether this upregulation occurs in adaption to oxidative stress, response to DNA damage or other mechanisms. These adaption mechanisms are hypothesized to be responsible for radiation resistance in tumor therapy that targets cancer cells through induction of oxidative stress (Huang et al. 2012). Even though the redox status of CSCs is largely unknown, it was shown that adult stem cells have a lower level of ROS than more mature cells, probably to maintain the stem cell character (Dayem et al. 2010, Huang et al. 2012). Therefore, it is assumed that CSCs have upregulated levels of antioxidant scavenger mechanisms that protect CSCs and contribute to radiation therapy resistance (Ogawa et al. 2013). Inhibition of the Hh pathway in a mouse model for ischemic stroke was shown to worsen brain damage by downregulation of Gli1, Ptch1 and Sod1 in neurons (Ji et al. 2012). Hh signaling also seems to protect neurons against oxidative stress by upregulation of SOD and glutathione peroxidase (Dai et al. 2011, Ji et al. 2012). Furthermore, SOD1-overexpressing glioma cells are less sensitive to radiation and SOD1 is upregulated in neuronal stem cells (Gao et al. 2008).
Consistent with our findings, several GLI1 target genes including proto-oncogenes CXCR4, BMI1 and $B C L-2$ and cyclins D1, D2 and E1 have been shown to contribute to pituitary adenoma pathogenesis. Strikingly, cyclin D positive cells also had a significantly higher expression of BCL-2 and Ki67 (Wang et al. 1996, Jordan et al. 2000, Turner et al. 2000a,b, Sanchez-Beato et al. 2006, Lee et al. 2010, Westerman et al. 2012).

In summary, our results expand the knowledge on $\mathrm{Hh}$ pathway members in pituitary tumorigenesis, indicating smoothened-independent activation of GLI1, which is positively linked to cell viability and correlates with SOX2, MKI67, TP53 and SOD1 expression. These data support the hypothesis that stem cell-like tumor cells are involved in the development of pituitary adenomas, nourishing the hope that those molecules could represent target genes for future therapeutic approaches.

\section{Declaration of interest}

The authors declare that there is no conflict of interest that could be perceived as prejudicing the impartiality of the research reported.

\section{Funding}

This research did not receive any specific grant from any funding agency in the public, commercial or not-for-profit sector.

\section{Author contribution statement}

$\mathrm{K}$ Lampichler designed and performed experiments, conducted research, analyzed data, interpreted results, wrote the manuscript and approved the final version. P Ferrer, M I Lutz and F Wolf conducted research and reviewed and approved the final manuscript. E Knosp and A Luger reviewed and approved the final manuscript. G Vila, L Wagner and S Baumgartner-Parzer reviewed the data, contributed to discussions, edited and approved the final manuscript.

\section{Acknowledgements}

The authors would like to thank Rita Lang for her exceptional technical assistance.

\section{References}

Andoniadou CL, Gaston-Massuet C, Reddy R, Schneider RP, Blasco MA, Le Tissier P, Jacques TS, Pevny LH, Dattani MT \& Martinez-Barbera JP 2012 Identification of novel pathways involved in the pathogenesis of human adamantinomatous craniopharyngioma. Acta Neuropathologica 124 259-271. (doi:10.1007/s00401-012-0957-9)

Andoniadou CL, Matsushima D, Mousavy Gharavy SN, Signore M, Mackintosh AI, Schaeffer M, Gaston-Massuet C, Mollard P, Jacques TS, Le Tissier P et al. 2013 Sox2(+) stem/progenitor cells in the adult mouse pituitary support organ homeostasis and have tumor-inducing potential. Cell Stem Cell 13 433-445. (doi:10.1016/j.stem.2013.07.004) 
Brechbiel J, Miller-Moslin K \& Adjei AA 2014 Crosstalk between Hedgehog and other signaling pathways as a basis for combination therapies in cancer. Cancer Treatment Reviews 40 750-759. (doi:10.1016/j.ctrv.2014. 02.003)

Briscoe J \& Therond PP 2013 The mechanisms of Hedgehog signalling and its roles in development and disease. Nature Reviews. Molecular Cell Biology 14 416-429. (doi:10.1038/nrm3598)

Chen J, Hersmus N, Van Duppen V, Caesens P, Denef C \& Vankelecom H 2005 The adult pituitary contains a cell population displaying stem/progenitor cell and early embryonic characteristics. Endocrinology 146 3985-3998. (doi:10.1210/en.2005-0185)

Dai RL, Zhu SY, Xia YP, Mao L, Mei YW, Yao YF, Xue YM \& Hu B 2011 Sonic Hedgehog protects cortical neurons against oxidative stress. Neurochemical Research 36 67-75. (doi:10.1007/s11064-010-0264-6)

Dayem AA, Choi HY, Kim JH \& Cho SG 2010 Role of oxidative stress in stem, cancer, and cancer stem cells. Cancers 2 859-884. (doi:10.3390/ cancers2020859)

De Sousa EMF, Vermeulen L, Fessler E \& Medema JP 2013 Cancer heterogeneity - a multifaceted view. EMBO Reports 14 686-695 (doi:10.1038/embor.2013.92)

Ezzat S, Asa SL, Couldwell WT, Barr CE, Dodge WE, Vance ML \& McCutcheon IE 2004 The prevalence of pituitary adenomas: a systematic review. Cancer 101 613-619. (doi:10.1002/cncr.20412)

Frank NY, Schatton T \& Frank MH 2010 The therapeutic promise of the cancer stem cell concept. Journal of Clinical Investigation 120 41-50. (doi:10.1172/JCI41004)

Gao Z, Sarsour EH, Kalen AL, Li L, Kumar MG \& Goswami PC 2008 Late ROS accumulation and radiosensitivity in SOD1-overexpressing human glioma cells. Free Radical Biology \& Medicine 45 1501-1509. (doi:10.1016/j.freeradbiomed.2008.08.009)

Garcia-Lavandeira M, Quereda V, Flores I, Saez C, Diaz-Rodriguez E, Japon MA, Ryan AK, Blasco MA, Dieguez C, Malumbres M et al. 2009 A GRFa2/Prop1/stem (GPS) cell niche in the pituitary. PLoS ONE 4 e4815. (doi:10.1371/journal.pone.0004815)

Garcia-Lavandeira M, Saez C, Diaz-Rodriguez E, Perez-Romero S, Senra A, Dieguez C, Japon MA \& Alvarez CV 2012 Craniopharyngiomas express embryonic stem cell markers (SOX2, OCT4, KLF4, and SOX9) as pituitary stem cells but do not coexpress RET/GFRA3 receptors. Journal of Clinical Endocrinology and Metabolism 97 E80-E87. (doi:10.1210/jc.2011-2187)

Gaston-Massuet C, Andoniadou CL, Signore M, Jayakody SA, Charolidi N, Kyeyune R, Vernay B, Jacques TS, Taketo MM, Le Tissier P et al. 2011 Increased Wingless (Wnt) signaling in pituitary progenitor/stem cells gives rise to pituitary tumors in mice and humans. PNAS $\mathbf{1 0 8}$ 11482-11487. (doi:10.1073/pnas.1101553108)

Gleiberman AS, Michurina T, Encinas JM, Roig JL, Krasnov P, Balordi F, Fishell G, Rosenfeld MG \& Enikolopov G 2008 Genetic approaches identify adult pituitary stem cells. PNAS 105 6332-6337. (doi:10.1073/ pnas.0801644105)

Herzog W, Zeng X, Lele Z, Sonntag C, Ting JW, Chang CY \& Hammerschmidt M 2003 Adenohypophysis formation in the zebrafish and its dependence on sonic Hedgehog. Developmental Biology 254 36-49. (doi:10.1016/S0012-1606(02)00124-0)

Huang TT, Zou Y \& Corniola R 2012 Oxidative stress and adult neurogenesis - effects of radiation and superoxide dismutase deficiency. Seminars in Cell \& Developmental Biology 23 738-744. (doi:10.1016/j.semcdb.2012.04.003)

Janicke RU, Sohn D \& Schulze-Osthoff K 2008 The dark side of a tumor suppressor: anti-apoptotic p53. Cell Death and Differentiation 15 959-976. (doi:10.1038/cdd.2008.33)

Ji H, Miao J, Zhang X, Du Y, Liu H, Li S \& Li L 2012 Inhibition of sonic Hedgehog signaling aggravates brain damage associated with the down-regulation of Gli1, Ptch1 and SOD1 expression in acute ischemic stroke. Neuroscience Letters 506 1-6. (doi:10.1016/j.neulet.2011.11.027)

Jordan S, Lidhar K, Korbonits M, Lowe DG \& Grossman AB 2000 Cyclin D and cyclin $\mathrm{E}$ expression in normal and adenomatous pituitary.
European Journal of Endocrinology/European Federation of Endocrine Societies 143 R1-R6. (doi:10.1530/eje.0.143R001)

Lee YH, Noh TW, Lee MK, Jameson JL \& Lee EJ 2010 Absence of activating mutations of CXCR4 in pituitary tumours. Clinical Endocrinology 72 209-213. (doi:10.1111/j.1365-2265.2009.03629.x)

Melmed S 2011 Pathogenesis of pituitary tumors. Nature Reviews. Endocrinology 7 257-266. (doi:10.1038/nrendo.2011.40)

Ogawa K, Yoshioka Y, Isohashi F, Seo Y, Yoshida K \& Yamazaki H 2013 Radiotherapy targeting cancer stem cells: current views and future perspectives. Anticancer Research 33 747-754.

Reiter MH, Vila G, Knosp E, Baumgartner-Parzer SM, Wagner L, Stalla GK \& Luger A 2011 Opposite effects of serum- and glucocorticoid-regulated kinase-1 and glucocorticoids on POMC transcription and ACTH release. American Journal of Physiology. Endocrinology and Metabolism 301 E336-E341. (doi:10.1152/ajpendo.00155.2011)

Sanchez-Beato M, Sanchez E, Gonzalez-Carrero J, Morente M, Diez A, Sanchez-Verde L, Martin MC, Cigudosa JC, Vidal M \& Piris MA 2006 Variability in the expression of polycomb proteins in different normal and tumoral tissues. A pilot study using tissue microarrays. Modern Pathology 19 684-694. (doi:10.1038/modpathol.3800577)

Sbrogna JL, Barresi MJ \& Karlstrom RO 2003 Multiple roles for Hedgehog signaling in zebrafish pituitary development. Developmental Biology $\mathbf{2 5 4}$ 19-35. (doi:10.1016/S0012-1606(02)00027-1)

Scales SJ \& de Sauvage FJ 2009 Mechanisms of Hedgehog pathway activation in cancer and implications for therapy. Trends in Pharmacological Sciences 30 303-312. (doi:10.1016/j.tips.2009.03.007)

Suliman M, Royds J, Cullen D, Timperley W, Powell T, Battersby R \& Jones TH $2001 \mathrm{Mdm} 2$ and the p53 pathway in human pituitary adenomas. Clinical Endocrinology 54 317-325. (doi:10.1046/j.13652265.2001.01195.x)

Tanizaki Y, Jin L, Scheithauer BW, Kovacs K, Roncaroli F \& Lloyd RV 2007 P53 gene mutations in pituitary carcinomas. Endocrine Pathology 18 217-222. (doi:10.1007/s12022-007-9006-y)

Trachootham D, Alexandre J \& Huang P 2009 Targeting cancer cells by ROS-mediated mechanisms: a radical therapeutic approach? Nature Reviews. Drug Discovery 8 579-591. (doi:10.1038/nrd2803)

Treier M, O'Connell S, Gleiberman A, Price J, Szeto DP, Burgess R, Chuang PT, McMahon AP \& Rosenfeld MG 2001 Hedgehog signaling is required for pituitary gland development. Development 128 377-386.

Turner HE, Nagy Z, Gatter KC, Esiri MM, Wass JA \& Harris AL $2000 a$ Proliferation, bcl-2 expression and angiogenesis in pituitary adenomas: relationship to tumour behaviour. British Journal of Cancer $\mathbf{8 2}$ 1441-1445. (doi:10.1054/bjoc.1999.1074)

Turner HE, Nagy Z, Sullivan N, Esiri MM \& Wass JA $2000 b$ Expression analysis of cyclins in pituitary adenomas and the normal pituitary gland. Clinical Endocrinology 53 337-344. (doi:10.1046/j.1365-2265. 2000.01088.x)

Vankelecom H \& Chen J 2014 Pituitary stem cells: where do we stand? Molecular and Cellular Endocrinology 385 2-17. (doi:10.1016/j.mce.2013. 08.018)

Vankelecom H \& Gremeaux L 2010 Stem cells in the pituitary gland: a burgeoning field. General and Comparative Endocrinology 166 478-488. (doi:10.1016/j.ygcen.2009.11.007)

Vila G, Theodoropoulou M, Stalla J, Tonn JC, Losa M, Renner U, Stalla GK \& Paez-Pereda M 2005a Expression and function of sonic Hedgehog pathway components in pituitary adenomas: evidence for a direct role in hormone secretion and cell proliferation. Journal of Clinical Endocrinology and Metabolism 90 6687-6694. (doi:10.1210/ jc.2005-1014)

Vila G, Papazoglou M, Stalla J, Theodoropoulou M, Stalla GK, Holsboer F \& Paez-Pereda M 2005b Sonic Hedgehog regulates CRH signal transduction in the adult pituitary. FASEB Journal 19 281-283.

Wang DG, Johnston CF, Atkinson AB, Heaney AP, Mirakhur M \& Buchanan KD 1996 Expression of bcl-2 oncoprotein in pituitary tumours: comparison with c-myc. Journal of Clinical Pathology 49 795-797. (doi:10.1136/jcp.49.10.795) 
Westerman BA, Blom M, Tanger E, van der Valk M, Song JY, van Santen M, Gadiot J, Cornelissen-Steijger P, Zevenhoven J, Prosser HM et al. 2012 GFAP-Cre-mediated transgenic activation of Bmi1 results in pituitary tumors. PLOS ONE 7 e35943. (doi:10.1371/journal.pone.0035943)

Xie J, Bartels CM, Barton SW \& Gu D 2013 Targeting Hedgehog signaling in cancer: research and clinical developments. OncoTargets and Therapy 6 1425-1435. (doi:10.2147/OTT.S34678)
Xu Q, Yuan X, Tunici P, Liu G, Fan X, Xu M, Hu J, Hwang JY, Farkas DL, Black KL et al. 2009 Isolation of tumour stem-like cells from benign tumours. British Journal of Cancer 101 303-311. (doi:10.1038/sj.bjc. 6605142)

Yauch RL, Gould SE, Scales SJ, Tang T, Tian H, Ahn CP, Marshall D, Fu L, Januario T, Kallop D et al. 2008 A paracrine requirement for Hedgehog signalling in cancer. Nature 455 406-410. (doi:10.1038/nature07275)

Received in final form 24 July 2015

Accepted 28 July 2015

Made available online as an Accepted Preprint

28 July 2015
Published by Bioscientifica Ltd. 